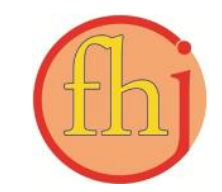

Faletehan Health Journal, 7 (2) (2020) 113-118

www. journal.Ippm-stikesfa.ac.id/ojs/index.php/FHJ

ISSN 2088-673X | e-ISSN 2597-8667

\title{
Hubungan Antara Keluhan Kelelahan Subjektif, Umur dan Masa Kerja Terhadap Produktivitas Kerja Pada Pekerja
}

\author{
Rizki Aulia Dina Safira ${ }^{1}$ Ela Nurdiawati ${ }^{*}$ \\ 1,2Program Studi Kesehatan Masyarakat, Universitas Faletehan \\ *Corresponding Author: elanurdiawati@gmail.com
}

\begin{abstract}
Abstrak
Produktivitas kerja merupakan hasil yang terukur, yang dapat dicapai oleh seseorang dalam lingkungan kerja yang nyata dalam setiap satuan waktu. Hasil dari studi pendahuluan terhadap 10 pekerja, terdapat 7 pekerja yang memiliki produktivitas kerja kurang baik. Penelitian ini bertujuan untuk mengetahui hubungan antara keluhan kelelahan subjektif, umur dan masa kerja terhadap produktivitas kerja pada pekerja di PT. KHI Pipe Industries tahun 2019. Desain penelitian yang digunakan adalah cross sectional. Populasi penelitian ini adalah seluruh pekerja di PT. KHI Pipe Industries yang berjumlah \pm 205 orang. Sampel dalam penelitian ini berjumlah 75 responden. Data penelitian didapatkan bahwa sebanyak 77,3\% termasuk kategori produktivitas kerja sedang, 68\% responden mengalami keluhan kelelahan ringan, usia responden termasuk kategori tua (82,7\%) dan masa kerja termasuk kategori sedang $(50,7 \%)$. Uji analisis menunjukkan tidak ada hubungan antara keluhan kelelahan subjektif $(\mathrm{Pv}=0,499)$ terhadap produktivitas kerja, terdapat hubungan antara umur $(\mathrm{Pv}=0,000)$ dan masa kerja $(\mathrm{Pv}=0,000)$ terhadap produktivitas kerja.
\end{abstract}

Kata Kunci: Kelelahan kerja, Masa kerja, Produktivitas kerja, Umur

\section{The Relationship Between Complaints of Subjective Fatigue, Age and Working Period with Work Productivity of Workers}

\begin{abstract}
Work productivity is a measurable result, which can be achieved by someone in a real work environment in each unit of time. The results of a preliminary study of 10 workers, there are 7 workers who have poor work productivity. This study aims to determine the relationship between complaints of subjective fatigue, age and working period with work productivity of workers at PT. KHI Pipe Industries in 2019. The research design used was cross sectional. The study population was all workers at PT. KHI Pipe Industries, amounting to \pm 205 people. The sample in this study amounted to 75 respondents. The research data found that $77.3 \%$ included in the category of moderate work productivity, $68 \%$ of respondents have complaints of mild fatigue, the age of the respondents included the old category (82.7\%) and the work period included in the moderate category (50.7\%). The analysis test shows that there is no relationship between subjective fatigue complaints $(P v=0.499)$ on work productivity, there is a relationship between age $(P v=0,000)$ and work period ( $P v=0,000$ ) on work productivity.
\end{abstract}

Keywords: Fatigue, Working periode, Work Productivity, Age 


\section{Pendahuluan}

Produktivitas kerja merupakan hal yang penting bagi suatu proses produksi yang sangat dipengaruhi oleh faktor internal dan eksternal. Faktor internal tersebut diantaranya beban kerja, kapasistas kerja serta faktor-faktor internal lingkungan kerja seperti kebisingan, penerangan yang tidak memenuhi standar dan faktor dari di tempat kerja lainnya. Faktor eksternal diantaranya adalah konflik dalam keluarga, isu-isu yang terkait dengan ketenagakerjaan, Peraturan-perundangan serta isu-isu sosial ekonomi budaya dan politik (Suma'mur, 2009). Faktor-faktor internal dan eksternal tersebut dapat menyebabkan terjadinya stres kerja, kelelahan kerja serta dapat berdampak terhadap kinerja maupun keselamatan dan kesehatan kerja. Oleh karena itu, perusahaan dituntut untuk menciptakan kondisi tempat kerja yang aman sehat dan memberikan kenyamanan bagi para pekerjanya melalui penerapan Keselamatan dan Kesehatan Kerja (K3). Penerapan K3 yang baik dan sesuai dengan ketentuan peraturan akan memunculkan rasa aman, nyaman dan sehat bagi pekerja sehingga produktivitas kerja dapat meningkat dan tentunya kecelakaan kerja juga dapat dicegah (Wulandari, 2018; Tarwaka, 2014). Penelitian Aulia, Aladin dan Tjendera (2018) menyebutkan bahwa terdapat hubungan yang signifikan antara kelelahan dengan kejadian kecelakaan di tempat kerja, pekerja yang mengalami kelelahan beresiko 2,7 kali mengalami kecelakaan kerja dibanding pekerja yang tidak lelah (Aulia, Aladin, Tjendera, 2018) dan kondisi tersebut tentunya akan berdampak terhadap produktivitas kerja. Beberapa penelitian menyebutkan bahwa terdapat berbagai faktor yang mempengaruhi produktivitas kerja diantaranya kelelahan, umur dan masa kerja.

Penelitian Verawati (2016) menyebutkan bahwa waktu kerja dan istirahat yang tidak sesuai dapat menyebabkan kelelahan kerja dan terdapat hubungan antara kelelahan subjektif pada pekerja pengemas kerupuk dengan produktivitas tenaga kerja. Pada penelitian tersebut menunjukkan bahwa responden dengan tingkat kelelahan kerja rendah mampu mengemas krupuk sesuai target sedangkan responden dengan tingkat kelelahan kerja sedang tidak mampu mengemas krupuk sesuai target. Penelitian lainnya juga menunjukkan bahwa jumlah pekerja yang merasakan kelelahan kerja ringan sebanyak 58,3\% dan kelelahan kerja sedang sebanyak $41,7 \%$, pekerja yang mempunyai produktivitas individu sesuai sebanyak $66,7 \%$ dan produktivitas individu tidak sesuai sebanyak $33,3 \%$ serta terdapat hubungan yang bermakna antara kelelahan kerja dengan produktivitas kerja individu (Putra, Sinaga, Mahyuni, 2015).

Produktivitas juga sangat ditentukan oleh usia/umur seseorang. Umur pekerja cukup menentukan keberhasilan dalam melakukan suatu pekerjaan. Pada umumnya, pekerja yang berumur tua mempunyai tenaga fisik yang lemah dan terbatas, sebaliknya tenaga kerja yang berumur muda mempunyai kemampuan fisik yang kuat (Mahendra, 2014). Hasil penelitian lainnya menunjukkan bahwa tingkat pendidikan, usia, pengalaman kerja dan jenis kelamin berpengaruh positif dan signifikan terhadap produktivitas tenaga kerja dengan variabel independen yang memiliki pengaruh dominan terhadap produktivitas tenaga kerja yaitu usia sebesar 2,331 (Ukkas, 2017).

Masa kerja juga mempengaruhi tingkat produktivitas yang akan dicapai. Semakin lama pekerja menekuni pekerjaannya maka akan terampil dan lebih cepat dalam menghasilkan produk tersebut. Hal ini dikarenakan dalam proses produksi diperlukan ketekunan dan keterampilan yang memadai. Pekerja yang memiliki masa kerja lebih lama memiliki kelebihan dalam mendeteksi, memahami dan mencari penyebab munculnya kesalahan dalam bekerja, sehingga dapat meminimalisir kesalahan dalam proses produksi. Namun, semakin meningkat masa kerjanya maka pekerja tersebut semakin beresiko terpapar penyakit yang ada di tempat kerja. Hasil penelitian terdahulu juga menunjukkan bahwa pengalaman kerja berpengaruh positif dan signifikan terhadap produktivitas kerja (Ukkas, 2017).

PT. KHI Pipe Industries merupakan perusahaan nasional yang telah menerapkan aspek K3 guna mencegah terjadinya kecelakaan kerja sehingga produktivitas kerja perusahaan senantiasa terjaga dan meningkat. Berdasarkan hasil studi pendahuluan yang dilakukan kepada 10 responden di PT. KHI, diketahui bahwa responden berada dalam kategori umur 20-30 tahun. Sebanyak 7 responden berada pada tingkat produktivitas yang buruk dan tiga responden mengalami keluhan kelelahan subjektif, tiga responden dengan umur sedang dan satu responden dengan masa kerja lama (> 10 tahun). Penelitian ini bertujuan untuk mengetahui hubungan antara keluhan kelelahan subjektif, umur dan masa kerja terhadap 
Faletehan Health Journal, 7 (2) (2020) 113-118

www. journal.Ippm-stikesfa.ac.id/ojs/index.php/FHJ ISSN 2088-673X | 2597-8667

produktivitas kerja pada pekerja di PT. KHI Pipe Industries tahun 2019.

\section{Metode Penelitian}

Penelitian ini merupakan penelitian kuantitatif dengan menggunakan desain studi cross sectional yang bertujuan untuk melihat hubungan antara keluhan kelelahan subjektif, umur dan masa kerja dengan produktivitas kerja, dimana data dicatat sesuai dengan kondisi yang ada yaitu diukur menurut keadaan atau status pada saat dilakukan observasi dan subjek hanya dioservasi sekali saja. Populasi dalam penelitian ini adalah seluruh pekerja di PT. KHI Pipe Industries sebanyak 205 orang. Besar sampel dalam penelitian ini sebanyak 75 orang yang diambil berdasarkan Rumus Slovin sebagai berikut:

$$
n=\frac{N}{1+\left(N x e^{2}\right)}
$$

Keterangan :

$\mathrm{n}$ : Besar sampel

$\mathrm{N}$ : Jumlah populasi

e : Batas toleransi error (error tolerance), batas error yang digunakan pada penelitian ini sebesar $10 \%$

Metode pengambilan sampel dilakukan secara simple random sampling. Instrumen penelitian berupa kuesioner berisi pertanyaan-pertanyaan untuk menggali tentang tingkat produktivitas kerja, kelelahan subjektif, umur dan masa kerja para pekerja. Kelelahan kerja diukur dengan menggunakan Subjective Self Rating Test dari Industrial Fatigue Research Committee (IFRC) Jepang. Kuesioner tersebut berisi 30 pertanyaan pelemahan kegiatan, pelemahan motivasi dan gambaran kelelahan fisik (Suma'mur, 2009). Kuesioner tidak dilakukan uji validitas dan reliabilitas karena menggunakan kuesioner yang sudah ditentukan oleh Industrial Fatigue Research Committee Jepang.

\section{Hasil dan Pembahasan}

Berdasarkan hasil penelitian diketahui bahwa produktivitas kerja karyawan menunjukkan kategori sedang, dengan keluhan kelelahan kategori ringan, usia karyawan rata-rata berada pada kategori tua serta masa kerja termasuk kategori sedang. Hasil penelitian terlihat pada tabel 1.

Tabel 1. Produktivitas Kerja, Keluhan Kelelahan Kerja, Umur dan Masa Kerja

\begin{tabular}{lcc}
\hline \multicolumn{1}{c}{ Variabel } & F & \% \\
\hline Produktivitas Kerja & & \\
$\quad$ Buruk & 9 & 12.0 \\
Sedang & 58 & 77.3 \\
Baik & 8 & 10.7 \\
\hline Keluhan Kelelahan & & \\
Subjektif & & \\
$\quad$ Tinggi & 0 & 0.0 \\
$\quad$ Sedang & 24 & 32.0 \\
$\quad$ Ringan & 51 & 68.0 \\
\hline Umur & & \\
Tua & 62 & 82.7 \\
Sedang & 13 & 17.3 \\
$\quad$ Muda & 0 & 0.0 \\
\hline Masa Kerja & & \\
$\quad$ Lama & 15 & 20.0 \\
$\quad$ Sedang & 38 & 50.7 \\
Baru & 22 & 29.3 \\
\hline Total & $\mathbf{7 5}$ & $\mathbf{1 0 0 . 0}$ \\
\hline
\end{tabular}

Produktivitas kerja di perusahaan akan berdampak terhadap eksistensi suatu perusahaan. Peningkatan produktivitas kerja hanya mungkin dilakukan oleh manusia. Faktor manusia yang mempengaruhi tingkat produktivitas kerja diantaranya masalah tidur, kebutuhan biologis, dan juga kelelahan kerja (Putra, Sinaga dan Mahyuni, 2015). Produktivitas kerja yang baik pwelu ditunjang oleh berbagai faktor, selain bahan baku dan tenaga kerja juga harus didukung oleh peralatan dan perlengkapan kerja yang sudah modern serta dengan adanya pemeriksaan kesehatan baik sebelum bekerja, berkala dan khusus. Faktor lain yang juga berdampak terhadap produktivitas kerja adalah kelelahan. Kelelahan yang terjadi pada karyawan akan mengganggu kinerja dan juga berpotensi menyebabkan terjadinya kecelakaan yang akan menyebabkan hilangnya waktu kerja, terhentinya proses produksi serta dampak lainnya. Tentu hal ini sangat mempengaruhi produktivitas kerja perusahaan.

Pada variabel penelitian keluhan kelelahan subjektif, hasilnya didominasi oleh pekerja yang mengalami keluhan kelelahan subjektif ringan (68\%). Penelitian ini sejalan dengan penelitian Verawati (2015) yang dilakukan kepada tenaga kerja bagian Pengemasan di CV. Sumber Barokah dengan pengelompokkan 3 kategori keluhan kelelahan subjektif (tinggi, sedang dan ringan) didapatkan hasil kelelahan subjektif tergolong pada kategori ringan (63\%). Kelelahan dalam setiap individu menunjukkan kondisi yang berbeda-beda, 
tetapi semuanya bermuara kepada kehilangan efisiensi dan penurunan kapasitas kerja serta ketahanan tubuh (Tarwaka, 2015). Gejala kelelahan yang dialami oleh tenaga kerja bisa bermacam-macam mulai dari penurunan kesiagaan dan perhatian, cara berpikir atau perbuatan anti sosial, penurunan dan hambatan persepsi, depresi, tidak cocok dengan lingkungan, kurang tenaga dan kehilangan inisiatif, sedangkan gejala lainnya dapat berupa sakit kepala

, vertigo, kehilangan nafsu makan, gangguan paru dan jantung serta gangguan kecemasan dan perubahan tingkah laku (Setyawati, 2010).

Pada variabel umur, dapat diketahui bahwa mayoritas pekerja memiliki umur tua $(82,7 \%)$. Hal ini sejalan dengan penelitian yang dilakukan oleh Muizzudin (2013), penelitian dilakukan terhadap Pekerja Tenun di PT. Alkatex Tegal, dengan hasil 75\% pekerja memiliki umur tua. Umur yang bertambah tua akan diikuti oleh kemampuan organ yang menurun sehingga menyebabkan tenaga kerja semakin mudah merasa lelah dan dapat menyebabkan penurunan produktivitas tenaga kerja itu sendiri (Muizzudin, 2013). Umur mempengaruhi seseorang dalam bekerja. Umur pekerja cukup menentukan keberhasilan dalam melakukan suatu pekerjaan. Pada umumnya, pekerja yang berumur tua mempunyai tenaga fisik yang lemah dan terbatas serta lebih rentan terkena penyakit akibat kerja (Mahendra, 2014).

Pada variabel masa kerja, dapat diketahui bahwa mayoritas pekerja memiliki masa kerja sedang $(50,7 \%)$. Hal ini sejalan dengan penelitian sebelumnya yang menunjukkan hasil 59,8\% karyawan yang memiliki masa kerja sedang serta sejalan dengan penelitian lainnya yang menyebutkan bahwa pekerja yang memiliki masa kerja lama lebih banyak $(74,0 \%)$ dibandingkan dengan pekerja yang mempunyai masa kerja baru (26,0\%) (Adiwinata dan Sutanto, 2014; Lestari, Kusuma, Pertiwi, 2018). Semakin lama masa kerja pekerja, maka produktivitas akan semakin tinggi. Masa kerja memberikan pengalaman kerja, pengetahuan dan ketrampilan kerja seorang karyawan. Semakin lama masa kerja karyawan maka pengalaman kerja yang dimiliki pun semakin banyak, sehingga hal ini akan berkontribusi terhadap produktivitas kerja yang tinggi (Ukkas, 2017).

\section{Hubungan Keluhan Kelelahan Subjektif dengan Produktivitas Kerja}

Tabel 2. Hubungan Keluhan Kelelahan Subjektif dengan Produktivitas Kerja

\begin{tabular}{|c|c|c|c|c|c|c|c|c|c|}
\hline \multirow{3}{*}{$\begin{array}{c}\text { Keluhan Kelelahan } \\
\text { Subjektif }\end{array}$} & \multicolumn{6}{|c|}{ Produktivitas Kerja } & \multirow{2}{*}{\multicolumn{2}{|c|}{ Jumlah }} & \multirow{3}{*}{ Nilai $p$} \\
\hline & \multicolumn{2}{|c|}{ Buruk } & \multicolumn{2}{|c|}{ Sedang } & \multicolumn{2}{|c|}{ Baik } & & & \\
\hline & $\mathbf{n}$ & $\%$ & $\mathbf{n}$ & $\%$ & $\mathbf{n}$ & $\%$ & $\mathbf{n}$ & $\%$ & \\
\hline Sedang & 3 & 12.5 & 17 & 70.8 & 4 & 16.7 & 24 & 100 & 0400 \\
\hline Ringan & 6 & 11.8 & 41 & 80.4 & 4 & 7.8 & 51 & 100 & 0.499 \\
\hline Jumlah & 9 & 12.0 & 58 & $\mathbf{7 7 . 3}$ & 8 & 10.7 & 75 & 100 & \\
\hline
\end{tabular}

Table 3. Hubungan Umur dengan Produktivitas Kerja

\begin{tabular}{|c|c|c|c|c|c|c|c|c|c|}
\hline \multirow{3}{*}{ Umur } & \multicolumn{6}{|c|}{ Produktivitas Kerja } & \multirow{2}{*}{\multicolumn{2}{|c|}{ Jumlah }} & \multirow{3}{*}{ Nilai $p$} \\
\hline & \multicolumn{2}{|c|}{ Buruk } & \multicolumn{2}{|c|}{ Sedang } & \multicolumn{2}{|c|}{ Baik } & & & \\
\hline & $\mathbf{n}$ & $\%$ & $\mathbf{n}$ & $\%$ & $\mathbf{n}$ & $\%$ & $\mathbf{n}$ & $\%$ & \\
\hline Tua & 9 & 14.5 & 51 & 82.3 & 2 & 3.2 & 62 & 100 & \\
\hline Sedang & 0 & 0 & 7 & 53.8 & 6 & 46.2 & 13 & 100 & 0.000 \\
\hline Jumlah & 9 & 12 & 58 & 77.3 & 8 & 10.7 & 75 & 100 & \\
\hline
\end{tabular}

Tabel 4. Hubungan Masa Kerja dengan Produktivitas Kerja

\begin{tabular}{|c|c|c|c|c|c|c|c|c|c|}
\hline \multirow{3}{*}{ Masa Kerja } & \multicolumn{6}{|c|}{ Produktivitas Kerja } & \multirow{2}{*}{\multicolumn{2}{|c|}{ Jumlah }} & \multirow{3}{*}{ Nilai $\mathbf{P}$} \\
\hline & \multicolumn{2}{|c|}{ Buruk } & \multicolumn{2}{|c|}{ Sedang } & \multicolumn{2}{|c|}{ Baik } & & & \\
\hline & $\mathbf{n}$ & $\%$ & $\mathbf{n}$ & $\%$ & $\mathbf{n}$ & $\%$ & $\mathbf{n}$ & $\%$ & \\
\hline Lama & 9 & 60 & 6 & 40 & 0 & 0 & 15 & 100 & \\
\hline Sedang & 0 & 0 & 36 & 94.7 & 2 & 5.3 & 38 & 100 & 0.000 \\
\hline Baru & 0 & 0 & 16 & 72.7 & 6 & 27.3 & 22 & 100 & \\
\hline Jumlah & 9 & 12 & 58 & 77.3 & 8 & 10.7 & 75 & 100 & \\
\hline
\end{tabular}


Faletehan Health Journal, 7 (2) (2020) 113-118

Berdasarkan tabel 2 terlihat bahwa responden yang memiliki tingkat keluhan kelelahan subjektif sedang lebih banyak dengan produktivitas kerja sedang $(70,8 \%)$, sedangkan responden yang memiliki tingkat keluhan kelelahan subjektif ringan lebih banyak dengan produktivitas kerja sedang $(80,4 \%)$. Hasil analisis menunjukkan tidak ada hubungan antara keluhan kelelahan subjektif dengan produktivitas kerja pada pekerja di PT. KHI Pipe Industries tahun 2019. Penelitian ini tidak sejalan dengan penelitian yang dilakukan oleh Verawati (2015) menyatakan bahwa ada hubungan yang signifikan antara kelelahan kerja dengan produktivitas kerja pada tenaga kerja bagian pengemasan di CV Sumber Barokah) (Verawati, 2015). Produktivitas kerja meningkat seiring dengan berkurangnya tingkat kelelahan kerja. Produktivitas kerja yang tidak sesuai target bisa dikarenakan oleh kelelahan kerja pada pekerja itu sendiri. Kelelahan fisik dan mental merupakan faktor penyebab terjadinya kondisi kelelahan yang berakibat terhadap turunnya produktivitas pekerja dalam melaksanakan tugasnya. Semakin tinggi tingkat kelelahan kerja seseorang, maka produktivitas dapat menurun (Verawati, 2015).

Kelelahan kerja bisa dicegah dengan berbagai macam cara diantaranya mengurangi peyebab timbulnya kelelahan. Para pekerja dapat melakukan peregangan otot misalnya menggerakkan kepala, tangan dan kakinya di selasela pekerjaannya ataupun saat istirahat. Perusahaan juga telah menerapkan waktu kerja dan waktu istirahat yang sesuai, agar pekerja tidak mudah mengalami kelelahan kerja.

\section{Hubungan Umur dengan Produktivitas Kerja}

Berdasarkan tabel 3 terlihat bahwa responden yang memiliki umur tua lebih banyak dengan produktivitas kerja sedang $(82,3 \%)$, sedangkan responden yang memiliki umur sedang lebih banyak dengan produktivitas kerja sedang $(53,8 \%)$. Hasil analisis menunjukkan terdapat hubungan antara umur dengan produktivitas kerja pada pekerja di PT. KHI Pipe Industries tahun 2019. Penelitian ini sejalan dengan penelitian yang dilakukan oleh Muizzudin (2013) pada Pekerja Tenun di PT. Alkatex Tegal, yang menyatakan bahwa terdapat hubungan yang signifikan antara umur dengan produktivitas kerja pada pekerja Tenun di PT. Alkatex Tegal dengan $(\mathrm{Pv}=0,798)$.
Hasil penelitian tidak sejalan dengan penelitian Aprilyanti yang menyebutkan bahwa usia dan lama bekerja tidak berpengaruh positif terhadap produktivitas kerja, dimana nilai probabilitas uji $\mathrm{F}$ nilai signifikansi untuk pengaruh usia dan masa kerja secara simultan terhadap produktivitas adalah sebesar 0,355 dan nilai F hitung 1,083. Penelitian Aprilyanti juga menyebutkan bahwa faktor usia dan masa kerja hanya memiliki pengaruh sebesar 8,3 persen $(\%)$ terhadap produktivitas kerja di perusahaan PT. Oasis Water International (Aprilyanti, 2017).

Umur adalah satuan waktu yang mengukur keberadaan suatu benda atau makhluk, baik yang hidup maupun mati. Umur dihitung sejak ia lahir hingga saat ini. Umur pekerja cukup menentukan keberhasilan dalam melakukan suatu pekerjaan, baik sifatnya fisik maupun non fisik. Pada umumnya, pekerja yang berumur tua mempunyai tenaga fisik yang lemah dan terbatas, sebaliknya pekerja yang berumur muda mempunyai kemampuan fisik yang kuat (Mahendra, 2014). Pada proses menua kondisi fisik seseorang akan mengalami perubahan jaringan pada tubuh, sehingga semakin bertambahnya umur seorang pekerja maka akan semakin berkurang kekuatan tubuh yang berakibat cepat mengalami kelelahan kerja. Umur yang semakin bertambah menjadi salah satu faktor yang dapat menimbulkan masalah kelelahan dalam bekerja. Selain fungsi organ-organ dalam tubuh menurun, pekerja dapat menjadi sensitif dan menjadi kurang produktif dalam pekerjaannya.

\section{Hubungan Masa Kerja dengan Produktivitas Kerja}

Berdasarkan tabel 4 terlihat bahwa responden yang memiliki masa kerja lama lebih banyak dengan produktivitas kerja buruk (60\%), kemudian responden yang memiliki masa kerja sedang lebih banyak dengan produktivitas kerja sedang $(94,7 \%)$, sedangkan responden yang memiliki masa kerja baru lebih banyak dengan produktivitas kerja sedang (72,7\%). Hasil analisis menunjukkan terdapat hubungan antara masa kerja dengan produktivitas kerja pada pekerja di PT. KHI Pipe Industries tahun 2019. Penelitian ini sejalan dengan penelitian yang dilakukan oleh Elia, Josephus dan Tucunan (2015) pada Tenaga Kerja Bongkar Muat di Pelabuhan Bitung yang 
menyatakan ada hubungan yang signifikan antara masa kerja dengan produktivitas kerja pada tenaga kerja bongkar muat di Pelabuhan Bitung.

Masa kerja merupakan jangka waktu orang sudah bekerja dari pertama mulai masuk hingga sekarang masih bekerja. Masa kerja dapat diartikan sebagai sepenggal waktu yang agak lama dimana seorang tenaga kerja masuk dalam satu wilayah tempat usaha sampai batas waktu tertentu (Suma'mur, 2009). Hasil yang penelitian yang dilakukan di PT. KHI Pipe Industries tahun 2019, menunjukkan bahwa sebagian besar pekerja memiliki masa kerja lebih dari 5 tahun sehingga semakin lama masa kerja pekerja maka produktivitas akan semakin tinggi. Pekerja yang memiliki masa kerja yang pendek beresiko terhadap hasil produktivitas kerjanya. Pekerja dengan masa kerja yang sudah lama memiliki pengalaman yang banyak, sehingga menghasilkan produktivitas kerja yang tinggi.

\section{Simpulan}

Penelitian ini menyimpulkan bahwa terdapat hubungan antara umur dan masa kerja dengan produktivitas kerja, sedangkan keluhan kelelahan subjektif tidak ada hubungan dengan produktivitas kerja.

\section{Referensi}

Adiwinata dan Sutanto. (2014). P(engaruh Kepuasan Kerja dan Motivasi Kerja terhadap Produktivitas Kerja Karyawan CV. Intaf Lumajang. Jurnal. Universitas Kristen Putra.

Aprilyanti, Selvia. (2017). Pengaruh Usia dan Masa Kerja Terhadap Produktivitas Kerja di PT. OASIS Water International Cabang Palembang. Jurnal Sistem dan Manajemen Industri, Vol. 1, No. 2: 68-72. Palembang.

Aulia, Aladin dan Tjendera. (2018). Hubungan Kelelahan Kerja dengan Kejadian Kecelakaan Kerja pada Pekerja Galangan Kapal. Jurnal Kesmas dan Gizi, Vol. 1 No.1.

Elia, Josephus dan Tucunan. (2015). Hubungan antara Kelelahan Kerja dan Masa Kerja dengan Produktivitas Kerja pada Tenaga Kerja Bongkar Muat di Pelabuhan Bitung Tahun 2015. Jurnal. Manado: Universitas Sam Ratulangi.

Lestari, Kusuma dan Pertiwi. (2018). Implementasi Hot Work Permit System sebagai Upaya
Pencegahan Kecelakaan Kerja. Faletehan Health Journa, Vol. 5, No. 1: 10-18. Serang: STIKes Faletehan.

Mahendra, A. (2014). Analisis Pengaruh Pendidikan, Upah, Jenis Kelamin, Usia dan Pengalaman Kerja terhadap Produktivitas Tenaga Kerja di Industri Kecil Tempe di Kota Semarang. Skripsi. Semarang: UNDIP.

Muizzudin, A. (2013). Hubungan Kelelahan dengan Produktivitas Kerja pada Pekerja Tenun di PT. Alkatex Tegal. Skripsi. Semarang: FIK UNNES.

Putra, Sinaga dan Mahyuni. (2015). Hubungan Kelelahan Kerja dengan Produktivitas Kerja pada Pekerja Bagian Produksi Tulangan Beton di PT. Wijaya Karya Beton Medan Tahun 2015. Medan: USU.

Sedarmayanti. (2009). Sumber Daya Manusia dan Produktivitas Kerja.

Setyawati. (2010). Selintas tentang Kelelahan Kerja. Yogyakarta: Amara Books.

Suma'mur. (2009). Keselamatan Kerja dan Pencegahan Kecelakaan. Jakarta: CV Haji Masagung.

Tarwaka. (2014). Keselamatan dan Kesehatan Kerja: Manajemen Implememntasi K3 di Tempat Kerja. Solo: Harapan Press.

Ukkas, Imran. (2017). Faktor-faktor yang Mempengaruhi Produktivitas Tenaga Kerja Industri Kecil Kota Palopo. Journal of Islamic Education Management, Vol. 2, No. 2: 187198.

Verawati, L. (2015). Hubungan Tingkat Kelelahan Subjektif dengan Produktivitas pada Tenaga Kerja bagian Pengemasan di CV Sumber Barokah. Jurnal Kesehatan dan Keselamatan Kerja. Jawa Timur: IAKMI.

Verawati, L. (2016). Hubungan Tingkat Kelelahan Subjektif dengan Produktivitas pada Tenaga Kerja Bagian Pengemasan di CV Sumber Barokah. Jurnal Kesehatan dan Keselamatan Kerja, Vol. 5, No. 1: 51-60

Wulandari, D. (2018). Hubungan antara Status Gizi, Usia, Motivasi Kerja, Pendidikan dan Pengalaman Kerja dengan Produktivitas Kerja di PT. Duta Sugar International Kabupaten Serang Tahun 2018. Skripsi. Serang: STIKes Faletehan. 